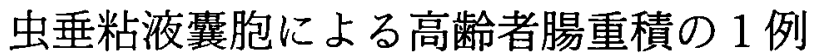

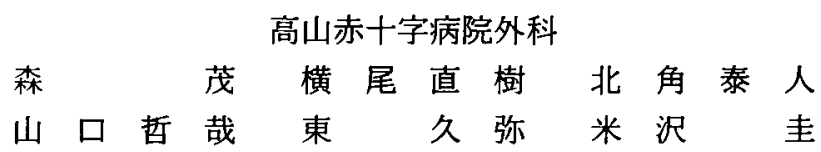

症例は 82 歳の女性, 腹痛と嘔吐を主訴に当院を受診した。腹部理学的所見にて右季助 部に嗂卵大弾性硬の腫瘤を触知し, また, 腹膜刺激症状を認めた。腹部単純 $\mathrm{X}$ 線検査で は小腸ガスとニボーを, 超音波検査では multiple concentric ring signを認め, 加えて 血液生化学的検查にて炎症反応と脱水所見を呈していたことより，絞拒性イレウスを 伴った腸重積と診断した. 即日開腹術を施行したところ, 手術所見で虫垂粘液襄胞が先 進部となった結腸型腸重積と判明し, 回盲部切除術を施行した. 病理組織学的に虫垂粘 液喜胞腺腫と診断された。

虫垂粘液桽胞による腸重積を超音波検查にて診断し, 即刻開腹術を施行して良好な結 果を得た症例を報告した。

索引用語：虫垂粘液表胞, 腸重積

\section{緒 言}

虫垂粘液胞は1842年の Rokitansky'による報告 以来，本邦でも400例以上の報告がある21. 本疾患の合 併症の 1 つに腸重積があるが比較的稀である。今回著 者らは，腹部超音波検查が術前診断に非常に有用で あった，虫垂粘液車胞による高齢者腸重積の 1 例を経 験したので，若干の文献的考察を加えて報告する.

\section{症例}

患者：82歳，女性.

主訴: 腹痛, 嘔吐.

既往歴：平成 8 年 1 月 16 日, 胆石・胆軎炎にて胆衰 摘出術, 70歳より高血圧, 糖尿病.

家族歴：特記すべき事なし。

現病歴：平成 8 年 3 月 18 日夕食後, 突然に間欠的腹 痛が出現し徐々に増強，同月20日より嘔吐が出現する と共に腹痛が持続性になったため，同月22日当科受診 となった。

入院時現症：身長 $145 \mathrm{~cm}$, 体重 $35 \mathrm{~kg}$, 体温 $36.5^{\circ} \mathrm{C}$, 血圧 $160 / 100 \mathrm{mmHg}$, 脈拍 $110 / \mathrm{min}$, 眼瞼結膜に軽度の 筫血あり, 腹部は軽度膨満と圧痛・反跳痛を認めたが 筋性防御はなく, 右季肋部に鷄卵大弾性硬のソーセ一 ジ様腫瘤を触知し, 腸蠕動はやや穴進していた。
入院時検査成績：軽度炎症反応, 高血糖, 低 $\mathrm{K}$ 低 $\mathrm{Cl}$ 血症，および尿アセトン陽性を認めた（表 1).

腹部単純 $\mathrm{X}$ 線写真検査 : 軽度拡張した小腸ガスお よび鏡面像を認めた（図 1)。

腹部超音波検査: 少量の腹水および右季肋部に multiple concentric ring signを認めた（図 2 ).

以上の所見より腸重積と診断, 発症より4 日が経過 しており絞抳性イレウスの併発が強く疑われたため, 即日開腹術を施行した。

手術所見：腰椎麻醉下に開腹すると, 横行結腸中央 にまで及ぶ腸重積と黄色透明な腹水を中等量認めた。 用手的に整復しながら検索したところ, 移動性盲腸预 よび, 腫大・緊満した虫垂の根部がさらに緊満し，ピ

表 1 入院時検查所見

\begin{tabular}{lc|lc}
\hline WBC & $10,500 / \mu \mathrm{l}$ & $\mathrm{CPK}$ & $46 \mathrm{IU} / l$ \\
$\mathrm{RBC}$ & $463 \times 10^{4} / \mu \mathrm{l}$ & $\mathrm{Na}$ & $139 \mathrm{mEq} / l$ \\
$\mathrm{Hb}$ & $12.8 \mathrm{~g} / \mathrm{dl}$ & $\mathrm{K}$ & $3.0 \mathrm{mEg} / l$ \\
$\mathrm{Ht}$ & $39.2 \%$ & $\mathrm{Cl}$ & $89 \mathrm{mEq} / l$ \\
$\mathrm{Mlt}$ & $24.8 \times 10^{4} / \mu \mathrm{l}$ & $\mathrm{BUN}$ & $13.3 \mathrm{mg} / \mathrm{dl}$ \\
$\mathrm{TP}$ & $7.4 \mathrm{~g} / \mathrm{dl}$ & $\mathrm{Cr}$ & $0.8 \mathrm{mg} / \mathrm{dl}$ \\
$\mathrm{Alb}$ & $3.9 \mathrm{~g} / \mathrm{dl}$ & $\mathrm{Glu}$ & $242 \mathrm{mg} / \mathrm{dl}$ \\
$\mathrm{GOT}$ & $38 \mathrm{IU} / l$ & $\mathrm{BE}$ & $10.7 \mathrm{mmol} / l$ \\
$\mathrm{GPT}$ & $30 \mathrm{IU} / l$ & $\mathrm{CRP}$ & $(+\mathrm{H})$ \\
$\mathrm{LDH}$ & $429 \mathrm{IU} / l$ & 杘アセトン & $(\mathrm{HH})$ \\
\hline
\end{tabular}




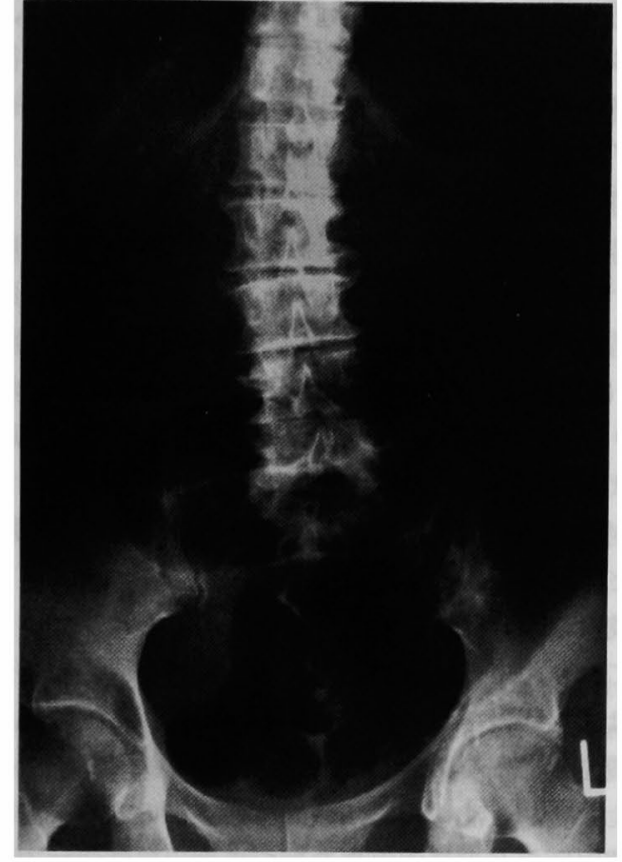

図 1 腹部単純 $\mathbf{X}$ 線写真 : 小腸ガスおよびニポーを 認めた。

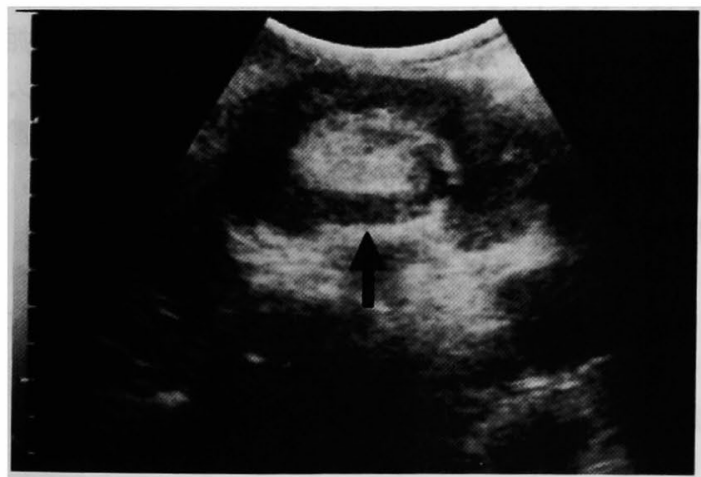

図 2 腹部超音波：右季肋部に multiple concentric ring sign を認めた.

ンポン玉大の腫瘤を形成して盲腸に嵌入，これが先進 部となった結腸重積と判明した，上記所見より虫垂粘 夜輁胞による腸重積と診断し, 回盲部切除術を施行し た. 尚, 盲腸, 上行結腸には発赤と浮腫を認めたが, 腸管の viability は十分に保たれていた。

術後経過は良好で, 術後19日目に退院した。

切除標本肉眼所見: 虫垂の長径は $10 \mathrm{~cm}$ で, 発赤・浮 腫を伴って腫大・緊満し, 根部は直径 $3 \mathrm{~cm}$ 大の球形に 緊満して盲腸に嵌入していた。虫垂と盲腸との交通は
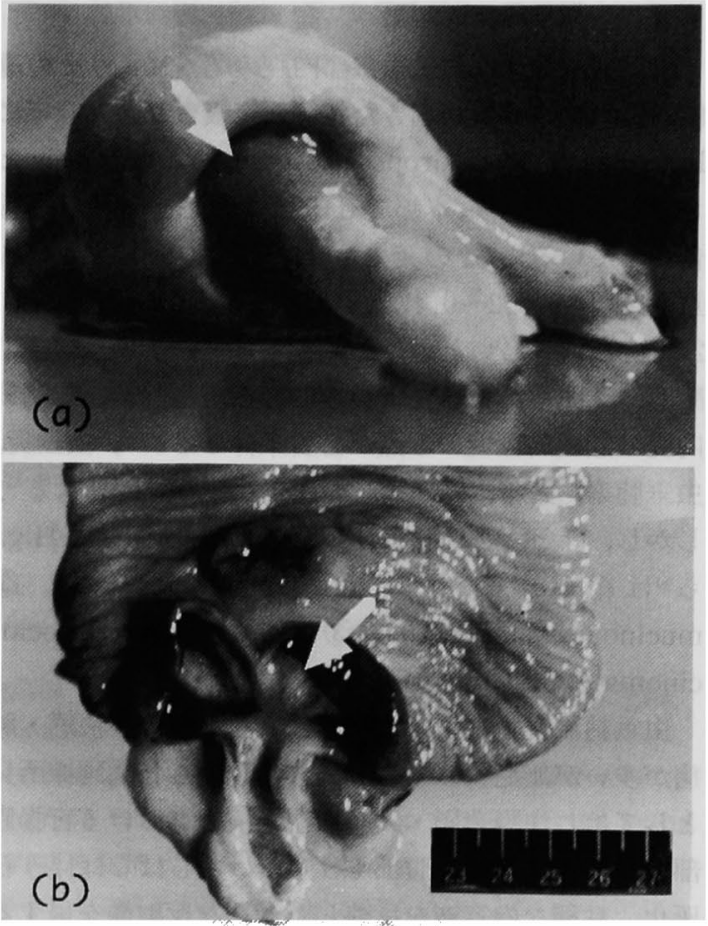

図 3 切除標本：球形に緊満した虫垂根部は盲腸に嵌 入（a), 粘膜面は均一であった (b).

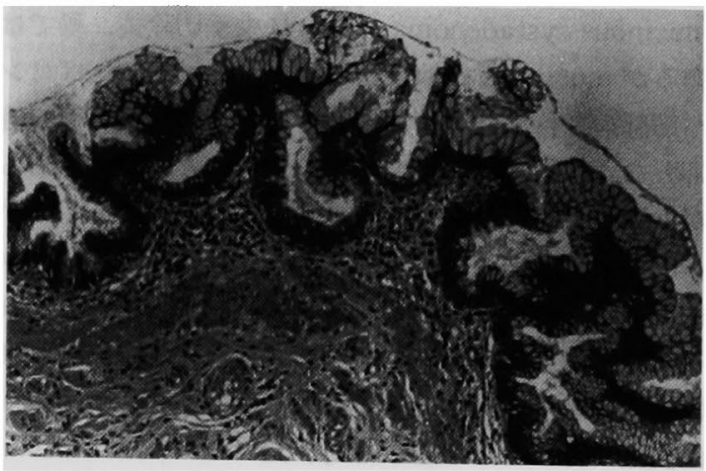

図 4 病理組織像 $(\mathrm{HE}$ 染色, $\times 10)$ ：虫垂根部の上皮 は粘液産生性の単層円柱上皮よりなり,一部に乳頭 状增殖と上皮の脱落を認めた。

なく, 虫垂の内腔は黄白色半透明寒天様粘液で満たさ れており, 粘膜面は均一であった（図３）。

病理組織学的所見: 盲腸, 回腸の上皮には異型性を 認めなかった。虫垂根部の上皮は粘液産生性の単層円 柱上皮よりなり, 一部に乳頭状増殖と上皮の脱落を認 めたが悪性像はなく, 虫垂粘液囊胞腺腫と診断された (図 4 ). 


\section{考案}

虫垂粘液壤胞は，虫垂根部内腔の閉塞によりその遠 位内腔に粘液貯留が起きた状態と定義され，1842年に Rokitansky ${ }^{1}$ が Hydrops processus vermiformis と して報告して以来,本邦でも1992年までに420余例が報 告されている゙2. その発生頻度は，磯垣ら゙によれば虫 垂切除例 $00.2 \sim 0.4 \%$, 剖検例 $00.07 \sim 0.4 \%$ で, 20〜60歳代に多いと言う。成因として，(1)虫垂根部の 閉塞，(2)閉塞部位より末梢での粘液産生貯留，(3)閉鎖 内腔の無菌的環境の 3 点が必要条件とされ゙，虫垂炎， 虫垂腫瘍，痹着，外部よりの圧迫などが原因となる ${ }^{5}$. しかし，ほとんどは腫瘍性病変が原因といわれ，Higa $ら^{6}$ は組織学的に, (1) mucosal hyperplasia, (2) mucinous cystadenoma, (3) mucinous cystadenocar. cinomaの 3 つに分類している.

虫垂粘液墴胞の症状としては，右下腹部不快感・鈍 痛が多いが無症状の場合も少なくない，各種画像所見 としては，注腸造影・大腸内視鏡検查における盲腸底 部の粘膜下腫瑒像，腹部 US におけるしばしば伴う石 灰化，粘稠な内容液を反映した微細な反射像を呈する 襄胞性病変, CT による盲腸を圧排する単房性または 多房性の低吸収領域2はどが有用な所見とされる2n?!

虫垂粘液襄胞の治療は, 非腫瘍性あるいは mucinous cystadenoma であれば虫垂切除術，稀では あるが mucinous cystadenocarcinomaであればリン パ節郭清を含めた回盲部あるいは右半結腸切除術の適 応となる。術前に良悪性を鑑別することは困難である

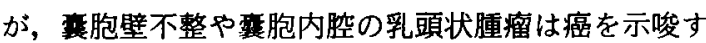
る所見とされることより ，かかる所見を認めたとき に悪性疾患に準じて検索，術式採用をすべきと思われ る.また，良性の adenomaであっても腹腔内に破れれて ば腹膜偽粘液腫を合併して予後不良であり，手術操作 は慎重に行わねばならない21。

虫垂粘液咅胞の合併症として, 腸重積・虫垂軸捻転・ 腹膜偽粘液腫・皎扼性イレウスなどが挙げられるが, そのうち腸重積合併例は1994年までに30例余りの報告 があり ${ }^{9}$ ，成人腸重積全体の $5 \%$ 前後を占めるに過ぎ ず比較的稀である 腸重積の本邦報告例29例を検討した結果，年秢は 21〜 86歳, 平均52.5歳, 40 70歳に多い傾向があり, 男女比は13：16でやや女性に多く，症状は腹痛と腫瘤 触知が多かったと報告している。

虫垂粘液嘦胞による腸重積の発生機序としては，盲 腸内腔に突出した襄胞が異物刺激となって回盲部の螦
動六進をきたした結果生ずると考えられておりら，ま た移動盲腸を合併する例が多い. 自験例では, 術後の 詳紐な問診により，2 力月前の胆摘術後に開始された 緩下剤服用後, 時々間欠的腹痛を自覚していたことが 判明し興味深い.

腸重積の診断は, 注腸造影でカニ爪様閉塞像, 腹部 US で multiple concentric ring sign, CT で特徵的層 状構造が描出されれば容易であるが，なかでも腹部 US は緊急時にも短時間で容易に質的診断まで可能て あり，その有用性については論を待たない ${ }^{899 !}$. 自験例 では先進部が横行結腸中央に存在し，腸管ガスのため 表胞部分は同定されなかったが，腹部 USのみで腸重 積と診断可能であった。

成人の腸重積は急性の経過を辿ることが少ないとさ れており，虫垂粘液襄胞による腸重積が原因での死亡 例は未だ報告されていない。しかし松村ら ${ }^{10} は$ は成人腸 重積の死亡率を $4.5 \%$ と報告しており，決して低率とは いえない。とくに，周知の如く自験例のような高跉者 で糖尿病などの基礎疾患を持つ患者の急性腹症では， 病態が理学的・血液学的所見に反映されないことがあ り, 重症度の判定や手術時期の判断を誤まった場合は 予後が著しく不良となる。自験例では, 腸重積と䛦断 した上で, 発症から長時間経過していることより饺扼 性イレウス合併を疑い,各種画像検査をあえて省略し, 緊急手術を施行した．救急疾患では，より効果的な診 断手技をもって迅速に対応することが重要と思われ， 腹部超音波検查の有用性を再認識した。

\section{結 語}

腹部超音波検查が術前検索に有用であった腸重積に て発症した虫垂粘液壤胞の 1 例を若干の文献的考察を 加えて報告した。

\section{文献}

1) Rokitansky KF: Beitrage zur Erkrankungen der Wurmfortsazentzundung. Wien Med Presse $26: 428-435,1866$

2）森田章夫, 望月 衛, 成田晃一：虫垂粘液裹胞の 2 例。日臨外医会誌 $55: 1503-1507,1994$

3）硪垣 弘, 島田俊恒：80墄の高齢者に見られた腸 重積を伴う虫垂粘液基腫の 1 例. 外科 $23: 732-$ 735,1961

4）薛 光明, 本間憲治, 在藤鍊一郎：虫垂粘液乘腫に よる回盲部腸重積症の 1 例. 外科診療 $20: 746-$ 748,1978

5）加藤聡之, 蜂須賀喜多男, 山口晃弘：腸重積をきた 
した虫垂粘液䑏胞の 1 例. 消外 $14 ： 757-762$, 1991

6) Higa E, Rosai J, Pizzimbono CA: Mucosal hyperplasia, mucinous cystadenoma, and mucinous cystadenocarcinoma of the appendix. Cancer 32 : 1525-1541, 1973

7）谷村慎哉, 東野正幸, 木下博明他：虫垂粘液萲胞の 2 例. 日臨外医会誌 $52: 2683-2689,1991$
8）松原俊樹,浦口 貴, 丸尾啓敏他：腸重積にて発症 した虫垂要胞腺癌の 1 例. 日臨外医会誌 $55: 430$ $-434,1994$

9）長谷川央, 小川 裕, 吉岡宣夫他：腸重積にて発症 した虫垂粘夜毫胞腺腫の 1 例. Gastrol Endosc $36: 1439-1444,1994$

10）松村長生：本邦の 40 外科施設におうる腸重積の現 状. 外科 $33: 951-955,1971$

\title{
AN AGED CASE OF APPENDICEAL MUCOCELE PRESENTING INTUSSUSCEPTION
}

\author{
Shigeru MORI, Naoki YOKOO, Yasuhito KITAKADO, Tetsuya YAMAGUCHI, \\ Hisaya AZUMA and Kei YONEZAWA \\ Department of Surgery, Takayama Red Cross Hospital
}

An 82-year-old woman was admitted to the hospital because of abdominal pain and vomiting. Abdominal physical findings revealed an elastic hard mass of hen's egg size in the right hypochondriac region and a peritoneal irritation sign. Abdominal Roentgenogram showed gaseous distension and niveau formation of the small intestine and abdominal ultrasonogram visualized a multiple concentric rign sign. On Laboratory examinations an inflammatory reaction and a dehydration were noted. Under a diagnosis of intussusception with strangulation ileus, she underwent a laparotomy on the same day. The operative findings showed the colic intussusception led through by appendiceal mucocele, and an ileocecal resection was performed. Histopathologically, it was diagnosed as mucinous cystadenoma of the appendix.

Being diagnosed as intussusception caused by appendiceal mucocele using abdominal ultrasonogram and operated on immediately, she achieved a favorable outcome. 